Anne Kjærgaard

Postdoc-stipendiat, Dansk Sprogncevn

\title{
Fra lidenskab til ligegyldighed - En caseanalyse fra Danmarks Domstole af et sprogpolitisk projekts (manglende) gennemslagskraft
}

\section{Resumé}

Artiklen prcesenterer en kvalitativ analyse af hvordan et sprogpolitisk projekt i Danmarks Domstole er slået igennem. Analysen omfatter både tekstlige og organisatoriske dimensioner, idet det undersøges dels om projektet har haft nogen gennemslagskraft i et udvalg af de tekster der produceres i organisationen, dels hvordan de tekstlige effekter hœnger sammen med den bredere organisatoriske kontekst projektet udspillede sig i. Tekstanalysen viser at det sprogpolitiske projekt fik en stærkt begrœnset gennemslagskraft i de analyserede tekster. I organisationsanalysen vises at de begrcensede tekstlige effekter skyldes en række kulturelle, strukturelle og individuelle faktorer, især dommeruafhængigheden og en meget stcrk antagelse lokalt i retterne om at skrivning af domme helt og holdent er dommeres egen sag.

\section{Indledning}

Siden 1960'erne har man forsøgt at gøre breve og andre tekster fra danske offentlige institutioner lettere at forstå for almindelige borgere og dermed også tegne et mere imødekommende billede af afsenderen. Denne bestræbelse kommer fx til udtryk i Vejledning om sproget $i$ love og andre retsforskrifter tilbage fra 1969 og Jarvad og Schack (2008) der er et noget nyere eksempel på samme tendens. Der er langt fra tale om en særlig dansk specialitet; tilsvarende bestræbelser kendes fra det øvrige Norden, fx uddeles der i Sverige og Norge årligt priser til offentlige myndigheder der gør en særlig indsats for at udtrykke sig på et klart og begribeligt sprog. Den internationale konference PLAIN, der afholdes hvert andet år, handler om forskellige aspekter af "plain language", altså sprogbrug der "meets the needs of its audience by using language, structure, and design so clearly and effectively that the audience has the best possible chance of really finding what they need, understanding it, and using it" (Cheek 2010: 9). Som konferenceprogrammet for PLAIN $2011^{1}$ vidnede om, er tendensen bredt internationalt forankret, fx arbejdes der med “plain language” i lande som Sydafrika og Mexico.

I Danmark har arbejdet med at ændre sprogbrugen i det offentlige (såvel som i private firmaer, især inden for forsikrings- og pensionsbranchen) særligt været knyttet til traditionen for sproglig rådgivning og sprogbrugsanalyse, se fx Hansen (1971), Rasmussen (1974) og Mortensen (1971). Som Kjøller påpeger, har sprogbrugsanalysen bl.a. “dannet svøb omkring en rckke håndvcrksagtige, og altså produktionsorienterede initiativer (bøger, kurser)” (2004: 37). I fokus for disse

\footnotetext{
${ }^{1}$ Se http://www.plain2011.com/images/stories/plain2011program.pdf
}
A. Kjærgaard
$1 / 28$
www.journals.uio.no 
"håndvcrksagtige" initiativer har især været rådgivning om hvordan tekster fra det offentlige skal udformes, se fx Møller \& Hansen (1981) og Poulsen (1976).

Den sproglige rådgivning har således i vidt omfang fokuseret på en primært praksisorienteret videreformidling af en række retningslinjer for hvordan man som ansat i det offentlige (eller private) kan skrive gode tekster til borgere (eller kunder). Det ringe forskningsmæssige fokus er ikke noget særligt dansk: I sin undersøgelse om forskning i klarsprogsarbejde ${ }^{2}$, mere specifikt forskning i "begriplighet i offentlig kommunikation", konkluderer Nyström Höög således at der ikke er særligt meget forskning inden for området (2010: 124). Shriver \& Gordon skriver at der er "limited research conducted specifically with a plain language agenda in mind" (2010: 33), og Becker Jensen (1998: 159) efterlyser mere specifikt "yderligere analyser der kan belyse forvaltningssproget set i lyset af dets institutionelle betingelser".

Her i artiklen underkaster jeg tekstlige og organisatoriske aspekter af arbejdet med at ændre sproget i offentlige institutioner en nærmere analyse. ${ }^{3}$ Jeg tager udgangspunkt i et konkret eksempel på et sprogpolitisk projekt, dvs. et projekt der har til formål at ændre på den måde man som offentlig institution eller privat virksomhed henvender sig til borgere eller kunder. Centrale komponenter i den slags projekter kan være at sende medarbejderne på kursus hvor de skal lære at skrive deres tekster på en anden måde, eller at udgive en vejledning eller regelsæt, en såkaldt "sprogpolitik", om hvordan tekster bør eller skal udformes. Mine hovedspørgsmål er:

- Hvad er de tekstlige effekter af det sprogpolitiske projekt i udvalgte medarbejderes tekster?

- Hvordan kan man, med udgangspunkt i den organisatoriske kontekst, forklare at det sprogpolitiske projekt (ikke) har haft bestemte effekter i forhold til de udvalgte medarbejderes tekster?

Spørgsmålene behandles i hver deres hovedafsnit: Det første spørgsmål besvares i afsnittet Det sprogpolitiske projekts tekstlige gennemslagskraft hvor jeg redegør for tekstanalysens data, metode og resultater. Det andet spørgsmål besvares i afsnittet Det sprogpolitiske projekts (manglende) gennemslagskraft i Danmarks Domstole hvor jeg opstiller en forklaring på hvorfor projektet ikke fik større gennemslagskraft.

Den case jeg fokuserer på her i artiklen, er et sprogpolitisk projekt i Danmarks Domstole. Eftersom der ikke er særligt meget forskning i spørgsmålet om sprogpolitiske projekters gennemslagskraft, kunne en række offentlige institutioner og private firmaer have udgjort lige så interessante cases. Bestræbelserne på at gøre sproget lettere at forstå for almindelige borgere

\footnotetext{
${ }^{2}$ Betegnelsen klarsprog stammer fra Sverige og bruges, særligt på svensk, om “det at 'udtrykke sig ligefremt og uden omsvøb"” (Sandersen 2005: 1).

${ }^{3}$ Artiklen er baseret på min ph.d.-afhandling (Kjærgaard 2010) der handler om sprogpolitiske projekter i to organisationer, nemlig Danmarks Domstole og Københavns Kommunes Teknik- og Miljøforvaltning.
}
A. Kjærgaard
$2 / 28$
www.journals.uio.no 
(eller for den sags skyld kunder) har dog traditionelt været tæt knyttet til juridisk sprogbrug, se fx Vejledning om sproget i love og andre retsforskrifter (1969) udgivet af Justitsministeriet og von Eybens kapitel Juridisk stil og sprogbrug i Juridisk Grundbog (1962: 480-517). At der traditionelt har været stærkt fokus på juridisk sprogbrug, skyldes nok at det er et felt hvor man på den ene side har tradition for at formulere sig så det er svært at forstå for lægfolk, og hvor man på den anden side ofte skriver tekster (fx domme, love og forsikringsbetingelser) som lægfolk kunne have interesse i at læse. Valget af Danmarks Domstole som case ligger således fint i forlængelse af det hidtidige fokus på juridisk sprogbrug.

Hvad angår spørgsmålet om de tekstlige effekter af sprogpolitiske projekter, tages det op i spredte kandidatspecialer, se fx Khan (2010), Carlsen (2008), Ramskov og Nederveen (2008). Derudover har Karker (1982) lavet en tekstanalyse af 1979-årgangen af Lovtidende for at undersøge effekterne af Justitsministeriets Vejledning om sproget i love og andre retsforskrifter fra 1969. Karker konkluderer at vejledningen har haft "betydelig indflydelse" (1982: 205), men undersøgelsen har validitetsproblemer: Formålet er at undersøge hvilken virkning Justitsministeriets vejledning har haft, men Karker undersøger snarere om vejledningen overholdes. For at kunne postulere et årsag-virknings-forhold mellem vejledningen og sproget i Lovtidende ville det som minimum være nødvendigt at undersøge udviklingen i tekster fra før og efter vejledningen blev udgivet - et forhold som jeg tager højde for i denne undersøgelse. Janssen (2001: 113-6) redegør desuden for resultaterne af en undersøgelse hvor effekten af et skrivekursus er blevet bedømt ved at tre eksterne bedømmere har vurderet tekster skrevet af offentligt ansatte før og efter de deltog i et bestemt skrivekursus. De eksterne bedømmere vurderede teksterne på træk som “effectiveness”, “comprehensibility” og “grammaticality” (ibid. 114). Undersøgelsen viser statistisk signifikante forskelle mellem tekster fra før og efter kurset, og viser således at sprogpolitiske projekter kan have tekstlige effekter.

Spørgsmålet om hvorfor sprogpolitiske projekter får en bestemt gennemslagskraft i organisationer, er heller ikke gjort til genstand for særligt mange undersøgelser, men er dog på forskellig vis taget op til overvejelse: Janssen (2001) udpeger en række træk ved det hollandske embedsværk der gør at skriveundervisning for de ansatte har svært ved at få nogen særlig gennemslagskraft i embedsværkets tekster, og Gunnarsson (1997) analyserer skrivearbejdet i en organisation med udgangspunkt i sociolingvistisk teori. Becker Jensen (1998) analyserer den organisatoriske kontekst for skrivearbejdet ved hjælp af sin såkaldte problemmodel (en model som jeg underkaster en grundig analyse og kritik i Kjærgaard (under bedømmelse)), Pedersen (2006) fokuserer særligt på spørgsmålet om hvordan forskellige diskurser i tekster fra det offentlige afspejler afsenderorganisationens kompleksitet, og Kjøller (1997) inddrager Scheins (1994) organisationskulturanalyse i forsøget på at forstå hvorfor det kan være svært at få skrivende medarbejdere i organisationer til at skrive anderledes.

Med udgangspunkt i den eksisterende forskning ønskede jeg at lave en undersøgelse der yderligere kunne bidrage til at sammenknytte tekst- og organisationsdimensionen, dvs. koble de tekstlige effekter af et sprogpolitisk projekt med den organisatoriske sammenhæng som projektet udspiller sig i - et tema som især Becker Jensen (1998) tager under behandling. I modsætning til 
det mere generelle perspektiv som Becker Jensen (1998) anlægger, var jeg drevet af en grundlæggende interesse for de enkeltindivider der befolker organisationer, og skriver tekster på organisationens vegne. Jeg var således særligt interesseret $\mathrm{i}$ at få et indblik i hvordan individuelle medarbejdere reagerede på sprogpolitiske projekter, og undersøgelsen blev derfor tilrettelagt som en kvalitativ analyse.

\section{Præsentation af casen - Danmarks Domstole}

Danmarks Domstole er en organisation der omfatter alle retter i Danmark, fra byretter til Højesteret, og Domstolsstyrelsen hvorfra det sprogpolitiske projekt udsprang. Jeg fokuserer særligt på Domstolsstyrelsen og Sø- og Handelsretten. Domstolsstyrelsen spiller en særlig rolle fordi den tog initiativ til det sprogpolitiske projekt. Sø- og Handelsretten spiller en særlig rolle fordi denne ret var meget åben over for at deltage i undersøgelsen og bl.a. stillede et kontor til min rådighed i forbindelse med min dataindsamling. Store dele af mine data stammer derfor fra Sø- og Handelsretten der beskæftiger sig med sager om sø- og handelsforhold, og sager om fx konkurs, betalingsstandsning og gældssanering. De analyserede data og de to centrale organisatoriske enheder, Domstolsstyrelsen og Sø- og Handelsretten, præsenteres nærmere efterhånden som jeg inddrager dem i analysen.

Det sprogpolitiske projekt blev sat i værk i 2001. På initiativ af den daværende direktør for Domstolsstyrelsen blev der nedsat et sprogudvalg der havde til opgave at finde ud af hvordan man kunne forbedre sproget ved domstolene. Alle skrivende medarbejdergrupper i Danmarks Domstole, dvs. dommere, dommerfuldmægtige, retsassessorer og kontorfunktionærer, havde repræsentanter i udvalget der derudover også bestod af direktøren for Domstolsstyrelsen, en kommunikationsmedarbejder fra Domstolsstyrelsen og en ekstern konsulent med ekspertise inden for sproglig rådgivning. Et af hovedresultaterne af sprogudvalgets arbejde var publikationen Sprogpolitik for Danmarks Domstole - en folder med en række anbefalinger for godt sprog og gode tekster der blev sendt ud til alle skrivende medarbejdere i Danmarks Domstole. I anledning af projektet blev der også lavet et temanummer af organisationens medarbejderblad (Danmarks Domstole, nr. 17). Domstolsstyrelsen opfordrede derudover de enkelte retter til at iværksætte lokale arrangementer (fx en temadag om sprog) og stillede midler til rådighed så retterne kunne søge om støtte til sådanne arrangementer (se Danmarks Domstole, nr. 17 (2003: 2)) ${ }^{4}$.

\footnotetext{
${ }^{4}$ I løbet af min dataindsamling lykkedes det mig desværre ikke at få noget overblik over hvor mange retter der faktisk havde benyttet sig af muligheden for at søge støtte.
} 


\section{Det sprogpolitiske projekts tekstlige gennemslagskraft ${ }^{5}$}

\section{Data - de analyserede tekster}

De analyserede tekster omfatter domme skrevet af to dommere fra Sø- og Handelsretten. Det var af resursehensyn nødvendigt at fokusere på en enkelt teksttype, og jeg valgte domme af to grunde. For det første fik jeg indtryk af at domme opfattes som den vigtigste type tekst der bliver skrevet i Danmarks Domstole, det er simpelt hen det skriftlige slutprodukt af domstolenes arbejde, mens fx breve og retsbøger ${ }^{6}$ snarere er en slags biprodukt, altså et resultat af det løbende arbejde med at få afviklet retssager. For det andet skrives domme i vidt omfang af dommere, og dommerne spiller en helt central rolle i organisationen hvad angår diskussioner om sprogbrug. I et af de interviews jeg lavede, spurgte jeg den tidligere direktør for Domstolsstyrelsen om der var nogle faggrupper i Danmarks Domstole hvor det var særligt nødvendigt at diskutere sprog og kvalitet, og han svarede:

Der er ingen tvivl om at dommergruppen er der hvor det er vigtigst (...) Og så selvsagt få dommere der jo sidder og konciperer en dom fra starten af, få dem til at tænke $i$ nye baner, at man kunne skrive det lidt anderledes og dermed mere forståeligt. (...) Man kan intet lave hos os hvis man ikke har en dommergruppe til at forstå og acceptere det her.

Direktøren påpeger altså at hvis ikke dommergruppen "forstå[r]" og "acceptere[r]" det sprogpolitiske projekt, så kan man “intet lave”. At dømme efter dette udsagn (og det var absolut ikke et udsagn der blev modsagt af min dataindsamling andre steder i Danmarks Domstole) opfattes dommere og de domme de skriver, altså som normsættende i forhold til andre medarbejdere og tekster i Danmarks Domstole.

Jeg fokuserede på to enkelte dommere fordi formålet var at lave en kvalitativ analyse af hvordan individuelle medarbejdere på forskellig vis forholder sig til projekterne. De to dommere blev udvalgt fordi jeg, på grundlag af interviews og etnografiske observationer, vurderede at de orienterede sig på forskellige måder i forhold til projekterne. Jeg inddrog altså ikke primært medarbejdere der afviste det sprogpolitiske projekt som irrelevant - hvilket man måske kunne få indtryk af hvis man alene kigger på resultaterne af min tekstanalyse. Dommene er udvalgt fra afgrænsede perioder før og efter det sprogpolitiske projekt. Jeg har medtaget alle de domme de to dommere skrev i de to perioder fordi jeg ønskede at undgå at udvælge bestemte domme som jeg fandt særligt repræsentative eller eksemplariske.

\footnotetext{
${ }^{5}$ Afsnittene om tekstanalyse er (bortset fra afsnittene om analysen af kancellisløjfer) en revideret version af Kjærgaard (2011).

${ }^{6}$ Retsbøger sendes ud til parterne for at holde dem orienterede i løbet af sagen, og de fungerer dermed som en slags breve.
}
A. Kjærgaard
$5 / 28$
www.journals.uio.no 
Tabel 1: data fra Sø- og Handelsretten

\begin{tabular}{|l|l|l|l|}
\hline Skribenter & $\begin{array}{l}\text { Tekster fra før det } \\
\text { sprogpolitiske projekt ("gamle } \\
\text { domme") }\end{array}$ & $\begin{array}{l}\text { Tekster fra efter det } \\
\text { sprogpolitiske projekt ("nye } \\
\text { domme”) }\end{array}$ & I alt \\
\hline D1, D2 & 24 domme (86.067 ord) & 24 domme (104.426 ord) & $\begin{array}{l}48 \text { domme } \\
(190.493 \\
\text { ord) }\end{array}$ \\
\hline
\end{tabular}

De "gamle” domme stammer fra 2002 og de "nye” fra 2007.

\section{Tre analysestrategier}

For at undersøge om og hvordan det sprogpolitiske projekt var blevet indarbejdet i de to dommeres tekster, anvendte jeg tre forskellige analysestrategier: en top down-strategi, en nuancerende analysestrategi og en eksplorativ strategi.

\section{Analysestrategi 1 - top down-analyserne}

Formålet med sprogpolitiske projekter er at regulere sproget på en bestemt måde, dvs. at fremme nogle sproglige og tekstlige træk og at fjerne eller minimere forekomsten af andre træk. Formålet med top down-analysestrategien er at sammenligne hvordan det står til med disse træk før og efter projektet. Udgangspunktet er i de tekstlige og sproglige effekter man, med udgangspunkt i en analyse af det sprogpolitiske projekt, kan forvente at finde i teksterne, og strategien er således deduktiv. Det ledende spørgsmål i top down-analyserne er altså om skribenterne følger de sproglige og tekstlige retningslinjer de er blevet anbefalet at følge.

Det var ikke nogen triviel opgave at finde ud af hvad skribenterne rent faktisk var blevet anbefalet at gøre. De anvisninger som de skrivende medarbejdere havde modtaget i Danmarks Domstole, blev som nævnt primært formidlet via folderen Sprogpolitik for Danmarks Domstole. Som tabel 2 viser, kan anvisningerne i publikationen kategoriseres i fire forskellige grupper. 
Tabel 2: anvisningstyper

\begin{tabular}{|c|l|}
\hline Anvisningstype & Eksempler \\
\hline 1. Værdimæssige anvisninger & $\begin{array}{l}\text { Denne anvisningstype består af vision, mission } \\
\text { og værdier, fx Danmarks Domstoles vision om } \\
\text { at “være en højt respekteret og tillidsskabende } \\
\text { organisation, der løser sine opgaver med } \\
\text { højeste kvalitet, service og effektivitet" } \\
\text { (Sprogpolitik for Danmarks Domstole, s. 2). }\end{array}$ \\
\hline $\begin{array}{l}\text { 2. Abstrakte tekstlige og sproglige } \\
\text { anvisninger }\end{array}$ & $\begin{array}{l}\text { Udformet som generelle beskrivelser af hvad } \\
\text { der skal kendetegne sprog og tekster fra } \\
\text { organisationen, fx at “[d]et er vigtigt, at } \\
\text { Danmarks Domstole kan kommunikere i et } \\
\text { klart og forståeligt sprog - på et } \\
\text { ubureaukratisk og nutidigt dansk" } \\
\text { (Sprogpolitik for Danmarks Domstole, s. 2). }\end{array}$ \\
\hline 3. Konkrete sproglige og tekstlige \\
retningslinjer & $\begin{array}{l}\text { Anvisninger der specifikt drejer sig om teksters } \\
\text { udformning, herunder disposition (fx brugen af } \\
\text { overskrifter), syntaks (fx kancellisløjfer), } \\
\text { leksikon (fx tilvalg og fravalg af bestemte ord) } \\
\text { og formalia (fx kommatering). }\end{array}$ \\
\hline 4. Eksempler & $\begin{array}{l}\text { Fx et forslag til en overskrift: "Stcevning. } \\
\text { Lykkekøing Kommune mod Jens Jensen" } \\
\text { (Sprogpolitik for Danmarks Domstole, s. 4). }\end{array}$ \\
\hline
\end{tabular}

De fire niveauer udgør analytiske kategorier, og i praksis kan der naturligvis være flydende grænser mellem dem. ${ }^{7}$

Jeg fandt det mest hensigtsmæssigt at fokusere på niveau 3, altså på konkrete sproglige og tekstlige anvisninger. Jeg betvivler ikke at tekster kan afspejle en given organisations mission og værdier (jf. niveau 1, de værdimæssige anvisninger), men udpegningen af en bestemt vision (at "vœre en højt respekteret og tillidsskabende organisation") giver ikke i sig selv nogen retningslinjer for hvordan en sådan vision skal komme til udtryk i teksterne. Niveau 2, abstrakte tekstlige og sproglige retningslinjer, er tydeligvis tættere knyttet til konkrete tekster, men er stadig relativt abstrakt; det giver fx ikke sig selv hvad der udgør "ubureaukratisk og nutidigt dansk” - og en undersøgelse af om det lykkes i teksterne, burde snarere inkludere en undersøgelse af modtagernes reception af teksterne.

\footnotetext{
${ }^{7}$ Tre af niveauerne (niveau 1, 2 og 3) har jeg indkredset med udgangspunkt i skriveguides fra Landsskatteretten og Danske Sundhedsorganisationers Arbejdsløshedskasse (Kjærgaard 2007). Niveauerne er således næppe unikke for det sprogpolitiske projekt i Danmarks Domstole. For andre kategoriseringer af anvisninger i skriveguider, se Henriksen, Jongejan \& Maegaard (2004: 85 ff.) og Solomon (1996: 288).
}
A. Kjærgaard 
Derudover virkede det umiddelbart overflødigt at give sig til at spekulere over hvad det helt præcist er for en type sprog der tilstræbes når der i Sprogpolitik for Danmarks Domstole fx står at "[d]et er vigtigt at Danmarks Domstole kan kommunikere i et klart og forståeligt sprog”. Man må formode at de konkrete sproglige og tekstlige anvisninger (niveau 3) faktisk udgør bud på hvad der karakteriserer sådan et sprog. Derimod er niveau 4-anvisningerne, altså eksemplerne, typisk for konkrete til at kunne fungere som udgangspunkt for en analyse: Det vil fx ikke give mening at undersøge et bredt udvalg af tekster fra Danmarks Domstole for overskriften "Stcevning: $[X] \bmod [X]$ " da eksemplet kun vil være relevant for teksttypen stævninger.

Man kan indvende at udgangspunktet i niveau 3-anvisningerne giver analyserne en temmelig formfokuseret karakter. Det er derfor for det første vigtigt at understrege at jeg ikke mener at det sprogpolitiske projekt i Danmarks Domstole nødvendigvis reducerer spørgsmålet om at teksterne skal udtrykke visionen om at "vœre en højt respekteret og tillidsskabende organisation, der løser sine opgaver med højeste kvalitet, service og effektivitet” (niveau 1) eller være formuleret på "et ubureaukratisk og nutidigt dansk" (niveau 2) til et spørgsmål om at fra- eller tilvælge bestemte sproglige og tekstlige træk (niveau 3). Det sprogpolitiske projekt er altså ikke nødvendigvis udtryk for en forestilling om at hvis bare man følger de konkrete sproglige og tekstlige retningslinjer, så er teksterne præcis som de skal være. De sproglige og tekstlige retningslinjer er imidlertid det mest håndgribelige svar der gives på spørgsmålet om i hvilken retning man søgte at regulere teksterne i Danmarks Domstole, og jeg valgte derfor at fokusere på disse træk.

For det andet var jeg meget varsom med at drage konklusioner om temaer der vedrørte niveau 1og 2-anvisninger, fx teksternes forståelighed. Som Wille (2001) har påpeget, er der udbredt konsensus blandt danske sproglige rådgivere om at en række anvisninger for godt sprog og gode tekster (anvisninger der i vidt omfang er repræsenteret i Sprogpolitik for Danmarks Domstole) resulterer i bestemte effekter for modtagerne af teksterne - $\mathrm{fx}$ at teksten bliver nemmere at forstå og virker mere imødekommende. Som Wille også påpeger, er det empiriske belæg for det synspunkt dog temmelig spinkelt - der er ikke lavet særligt mange undersøgelser der kan vise hvilke effekter det har for læserne hvis teksterne følger de traditionelle anvisninger for godt sprog og gode tekster. Jeg havde ikke resurser til at give mig i kast med den slags analyser (men er netop gået i gang med et postdocprojekt der skal undersøge spørgsmålet om effekten for læserne). Af disse grunde nøjedes jeg i top down-analyserne med at undersøge om skribenterne faktisk fulgte niveau 3-anvisningerne, men vender dog tilbage til niveau 1- og 2-anvisningerne i de eksplorative analyser. ${ }^{8}$

\footnotetext{
${ }^{8}$ En tredje forklaring, der dog ikke har nogen særlig relevans i denne artikel, er at jeg i min afhandling var ude i et metodisk ærinde: Jeg ville undersøge om man kunne opstille en metode til at måle de tekstlige effekter af sprogpolitiske projekter - og dette delformål var med til at trække analyserne i retning af et fokus på sprogtræk der var relativt lette at kvantificere.
} 


\section{Resultater af top down-analyserne}

Tabel 3 viser resultaterne af de top down-analyser jeg gennemførte. Analyserne omfatter brugen af overskrifter (dvs. brugen af anbefalede overskrifter som "Parternes synspunkter" i stedet for det mere traditionelle “Anbringender”), sætningslængde, brugen af passiver, kancellisløjfer (altså konstruktioner af typen "en af retten udmålt straf”), minusord (dvs. ord som de skrivende medarbejdere blev frarådet at bruge, fx ord som "skrivelse" og "fremsende") og verbalsubstantiver.

For hver analyse blev der, med udgangspunkt i de relevante niveau 3-anvisninger, formuleret et eller flere succeskriterier - for sætningsanalysen gælder det $\mathrm{fx}$ at sætningerne skal være kortere i de nye domme end i de gamle. Succeskriteriet for hver analyse står i kolonne 2 i skemaet. "Gamle” og "nye” domme er domme der er skrevet hhv. før og efter det sprogpolitiske projekt blev sat i værk.

Tabel 3: resultater af top down-analyserne. Signifikansniveauet er sat til 0,01.

\begin{tabular}{|l|c|l|l|}
\hline Sprogligt træk & Succeskriterium & D1 & D2 \\
\hline Overskrifter & $\begin{array}{l}\text { Der er signifikant flere af de overskrifter der anbefales } \\
\text { i Sprogpolitik for Danmarks Domstole, i de nye } \\
\text { domme end i de gamle domme. }\end{array}$ & $\mathbf{J a}$ & Nej \\
\hline Sætningslængde & $\begin{array}{l}\text { Sætningerne i de nye domme har en kortere gennem- } \\
\text { snitlig længde end sætningerne i de gamle. }\end{array}$ & $\mathbf{N e j}^{\mathbf{9}}$ & $\mathbf{N e j}$ \\
\hline Passiver & $\begin{array}{l}\text { Der er signifikant færre s- og blive-passiver i de nye } \\
\text { domme end i de gamle. }\end{array}$ & $\mathbf{N e j}$ & Nej \\
\hline Kancellisløjfer & $\bullet \quad \begin{array}{l}\text { Der er signifikant færre kancellisløjfer i de nye } \\
\text { domme end i de gamle. }\end{array}$ & $\mathbf{N e j}$ & $\mathbf{N e j}$ \\
\hline Minusord & $\begin{array}{l}\text { Der er signifikant færre minusord i de nye domme end } \\
\text { i de gamle. }\end{array}$ & $\mathbf{N e j}$ & $\mathbf{N e j}$ \\
\hline Verbalsubstantiver & $\bullet \quad \begin{array}{l}\text { Der er signifikant færre verbalsubstantiver i de nye } \\
\text { domme end i de gamle. }\end{array}$ & $\mathbf{N e j}$ & $\mathbf{N e j}$ \\
\hline Antal opfyldte succeskriterier & $\mathbf{1}$ & $\mathbf{0}$ \\
\hline
\end{tabular}

Der er taget højde for at fx minusord, kancellisløjfer og passiver kan stamme fra "fremmed" tekst, altså tekst som dommerne har citeret fra andre kilder. Ved hjælp af forskellige former for opmærkning af teksterne var jeg i stand til at frasortere denne type tekst. ${ }^{10}$ Analyserne af fx

\footnotetext{
${ }^{9}$ Den grå skravering markerer at det af tekniske årsager ikke var muligt at teste for statistisk signifikans.

${ }^{10}$ Jeg opmærkede kun eksempler på manifest intertekstualitet, hvorved jeg forstår citater der er tydeligt markeret som citater, fx vha. anførselstegn, ændret skriftstørrelse, indrykning eller lignende. Opmærkningen omfatter altså ikke tekstdele som skribenterne har kopieret uden at markere dem som citater.
}
A. Kjærgaard
$9 / 28$
www.journals.uio.no 
minusord, kancellisløjfer og passiver omfatter derfor kun den tekst som skribenterne selv må formodes at have formuleret.

De to dommere har opfyldt hhv. 1 og 0 af de opstillede succeskriterier. Det overordnede resultat af top down-analyserne er således at der ikke er særligt stor forskel på gamle og nye domme, dvs. at det sprogpolitiske projekt ikke, eller i hvert fald i meget ringe grad, har haft effekter for de analyserede tekster.

\section{Analysestrategi 2 - nuancerende analyser}

Det er oplagt at et sprogpolitisk projekts tekstlige gennemslagskraft kan komme til udtryk på mange andre måder end dem der er i fokus ved top down-analysestrategien. De nuancerende analyser skulle vise om der var andre tegn på forandring i forbindelse med et givet tekstligt eller sprogligt træk end resultaterne af top down-analysen umiddelbart lod ane.

\section{Resultater af de nuancerende analyser}

Kort sagt viste de nuancerende analyser ikke flere tegn på at projektet har betydet ændringer for de analyserede domme, end top down-analyserne. For at vise hvordan analysestrategi 2 blev udfoldet, vil jeg give et eksempel på en nuancerende analyse, nemlig analysen af kancellisløjer. Betegnelsen kancellisløjfer (der af Becker Jensen kaldes "foranstillet bestemmelse” (1998: 70)) dækker over konstruktioner som “de i påstand $X$ anførte handlinger” og "en af retten udmålt straf'. Der er altså tale om nominalfraser der typisk består af pronomen + præpositionsforbindelse(r) + adjektiv/præsens participium/perfektum participium + substantiv. Den relevante anvisning i Sprogpolitik for Danmarks Domstole lyder "[s] kriv ligefremt - brug ikke bagvendte ordstillinger" (s. 10). Som eksempler på sådanne "bagvendte ordstillinger" nævnes en række kancellisløjfer, fx “de af sagsøgeren medsendte bilag” (s. 9).

Top down-analysen viste at der ikke var signifikante forskelle mellem antallet af kancellisløjfer i nye og gamle domme, dvs. at der ikke var signifikant færre kancellisløjfer i de nye domme. I de nuancerende analyser valgte jeg imidlertid at se nærmere på to andre aspekter af kancellisløjfer, nemlig længde og grad af formelkarakter.

Udgangspunktet er altså at kancellisløjfe-konstruktionen kan miste terræn på andre måder end ved at blive mindre hyppig, fx ved at blive kortere. En sådan ændring i kancellisløjfers længde kunne være tegn på at dommerne tager højde for det sprogpolitiske projekt i deres domme - om end det ikke er på en måde man umiddelbart kunne forvente med udgangspunkt i det sprogpolitiske projekt, nærmere bestemt Sprogpolitik for Danmarks Domstole, der ikke tematiserer længden af kancellisløjfer. Længden af kancellisløjfer kan variere betragteligt. En kancellisløjfe er på mindst 5 ord (jf. beskrivelsen ovenfor), mens den længste i de analyserede domme er på 21 ord.

Den nuancerende analyse viser ingen statistisk signifikante forskelle på længden af kancellisløjfer i gamle og nye domme:
A. Kjærgaard
$10 / 28$
www.journals.uio.no 
Tabel 4: gennemsnitlig kancellisløjfelængde (D1)

\begin{tabular}{|l|l|l|l|}
\hline & Gamle domme & Nye domme & Forskel \\
\hline Gennemsnitligt antal ord pr. kancellisløjfe & 6,2 & 7,2 & +1 \\
\hline
\end{tabular}

Mann-Whitney $\mathrm{U}=456,5, \mathrm{n}_{1}=26, \mathrm{n}_{2}=30, \mathrm{p}=0,140$ (enhalet)

Tabel 5: gennemsnitlig kancellisløjfelængde (D2)

\begin{tabular}{|l|l|l|l|}
\hline & Gamle domme & Nye domme & Forskel \\
\hline Gennemsnitligt antal ord pr. kancellisløjfe & 6,9 & 7,5 & $+0,6$ \\
\hline
\end{tabular}

Mann-Whitney $\mathrm{U}=180, \mathrm{n}_{1}=18, \mathrm{n}_{2}=19, \mathrm{p}=0,397$ (enhalet)

Beregningerne ovenfor viser altså at når man tester forskellene i længden af kancellisløjfer for statistisk signifikans vha. den statistiske test Mann-Whitney U, så viser det sig at der ikke er nogen signifikante forskelle mellem gamle og nye domme hos nogen af dommerne: P-værdierne på hhv. 0,140 og 0,397 falder ikke ind under det fastsatte signifikansniveau på 0,01, dvs. testen viser at forskellene mellem gamle og nye domme er tilfældig.

I næste nuancerende analyse så jeg på hvilken grad af formelkarakter der kendetegner kancellisløjferne hos de to dommere. Udgangspunktet er Søndergaards påstand om at kancellisløjfer "stort set kun [findes] i nedarvede standardfraser som "de i § 2 næevnte betingelser" og "de i bekendtgørelsen fastsatte bestemmelser"” (2010: 7). Jeg undersøgte således om kancellisløjferne over tid (altså fra gamle til nye domme) antager en mere fast og formelagtig karakter.

"Formulaicity", altså formelkarakter, er ifølge Perkins "manifested in strings of linguistic items where the relation of each item to the rest is relatively fixed, and where the substitutability of one item by another of the same category is relatively constrained" (citeret efter efter Wray og Perkins, 2000: 1, mine fremhævelser). Man kan kritisere denne definition af formularisk sprog for at være meget åben. Hvad skal der fx til for at man kan sige at forbindelsen mellem en sproglig enhed ("linguistic item") og resten af de sproglige enheder er "relatively fixed"? Imidlertid var definitionen et godt udgangspunkt for undersøgelsen af kancellisløjfers mulige formelkarakter der gik ud på at undersøge om brugen af kancellisløjfer på en eller anden måde er begrænset, fx ved at konstruktionen kun optræder i form af et begrænset antal faste udtryk, eller ved at kancellisløjfer altid behandler et bestemt emne.

I D1's gamle domme er der en række gentagelser af kancellisløjfer i de samme domme, fx “de til hjemmesiden hørende underliggende metatags" (gentages 3 gange i den samme dom). Kancellisløjferne gentages maksimalt 3 gange i de analyserede domme, og de er alle meget sagsspecifikke; “de til hjemmesiden hørende underliggende metatags” er fx knyttet til en ganske bestemt sag om et bestemt emne, og det er svært at forestille sig at denne formulering skulle vinde nogen større udbredelse. Disse kancellisløjfer må derfor karakteriseres som en slags "lejlighedsdannelser" og viser ikke tegn på at brugen af kancellisløjfer er knyttet til bestemte faste vendinger. 
Frasen “det under (påstand) $X$ ncevnte $X$ ” forekommer 4 gange i D1's gamle domme. I disse tilfælde tjener kancellisløjfen en funktion der ofte er behov for i domme, nemlig at henvise til hvad der står i parternes påstande, altså det de gør krav på i sagen. De 4 kancellisløjfer optræder imidlertid i den samme dom. Det tyder ikke på at der er tale om et fast udtryk som D1 i almindelighed bruger i sine domme. Man kunne snarere få en fornemmelse af at det er et udtryk der har fundet vej til dommen fordi en eller flere af de advokater der har udarbejdet sagsdokumenterne (der udgør en væsentlig del af grundlaget for den færdigskrevne dom), ynder at bruge det. D1's brug af kancellisløjfer synes således at bekræfte Becker Jensens observation om at kancellisløjfer kan forekomme hvor der skrives efter forlæg (1998: 70-71).

Hvad angår D1's nye domme, er det mest interessante at der forekommer en række kancellisløjfer der synes at være bygget op omkring samme, grundlæggende formel:

Tabel 6: Kancellisløjfer i D1’s nye domme

\begin{tabular}{|l|l|l|}
\hline & Kancellisløjfe & $\begin{array}{l}\text { Antal } \\
\text { forekomster }\end{array}$ \\
\hline 1 & De i bilag 1, 2, 4, 5 og 6 anførte angivelser & 1 \\
\hline 2 & De i påstand I anførte handlinger & 4 \\
\hline 3 & $\begin{array}{l}\text { De i bilag 4, } 5 \text { og } 6 \text { samt i påstand I under a, b og c. udspredte urigtige og vildledende } \\
\text { angivelser }\end{array}$ & 1 \\
\hline 4 & De i påstand I, a, b og c anførte udtalelser & 1 \\
\hline 5 & De i påstand I nævnte handlinger & 1 \\
\hline 6 & Det i stævningens påstand I c nævnte citat & 1 \\
\hline 7 & Den i påstand I angivne anerkendelsespåstand & 1 \\
\hline 8 & De i påstand II - VI påståede yderligere retsfølger & 1 \\
\hline 9 & De i påstand I opregnede handlinger & 1 \\
\hline 10 & Den i anklageskriftet anførte mail & 1 \\
\hline
\end{tabular}

Alle disse kancellisløjfer følger strukturen [præpositionsforbindelse der angiver sagsdokument] + [participiumsform af ytringsverbum]. Der er imidlertid det særlige ved formlen at den i 12 ud af 13 tilfælde optræder i den samme dom - og dermed ikke synes at være en formel D1 i almindelighed anvender i sine domme. Således tyder det også her på at kancellisløjferne er et resultat af afsmitning fra de dokumenter der ligger til grund for sagen.

Hvad angår D2's brug af kancellisløjfer, er der i de gamle domme ikke nogen ordrette gentagelser af kancellisløjfer. Der er således ikke tegn på kancellisløjfer med formelagtig karakter i D2's gamle domme. I D2's nye domme gentages kancellisløjferne “de af sagsøger registrerede varemcerker” og “den af Skat København den [dato] trufne beslutning” 6 gange hver. Ingen af kancellisløjferne optræder i flere domme, dvs. begge gentages 6 gange i hver sin dom. Således er der meget der tyder på at dommerne overtager sagsakternes sprogbrug, men ikke at dommerne i almindelighed selv anvender bestemte formelagtige kancellisløjfer i deres domme.
A. Kjærgaard
$12 / 28$
www.journals.uio.no 
Analysen af kancellisløjfer er her trukket frem som et eksempel på at heller ikke en nærmere granskning af resultaterne fra top down-analyserne viste nogen særlige forskelle mellem gamle og nye domme: Den nuancerende kancellisløjfeanalyse tyder ikke på at dommerne indarbejder anbefalingerne om kancellisløjfer på andre måder end dem man umiddelbart kunne forvente med udgangspunkt i en analyse af de sproglige og tekstlige anvisninger der blev promoveret i det sprogpolitiske projekt.

\section{Analysestrategi 3 - eksplorative analyser}

De eksplorative analyser er induktive: Udgangspunktet er helt at se helt bort fra det sprogpolitiske projekts anvisninger og i stedet undersøge om der er forskelle mellem de gamle og de nye tekster som hverken top down- eller den nuancerende analysestrategi kunne indfange. Den eksplorative analysestrategi har to formål: For det første skal den vise om der er effekter af det sprogpolitiske projekt som man ikke ville forvente med udgangspunkt i niveau 3-anvisningerne, og analysestrategien gav mig således mulighed for at inddrage niveau 1- og 2-anvisningerne i analysen. Fx kunne man forestille sig en skrivende medarbejder der, uden at tage synderligt hensyn til de konkrete sproglige og tekstlige anvisninger (niveau 3), hæfter sig ved formuleringer som fx "tillidsskabende organisation” eller “klart og forståeligt sprog” og indarbejder disse elementer i teksterne på andre måder end dem man kunne forvente med udgangspunkt i niveau 3anvisningerne.

For det andet kompenserer den eksplorative analyse for at det var uden for den afsatte tidsramme at gennemføre alle de top down-analyser som det sprogpolitiske projekt gav anledning til (man kunne have lavet 27 top down-analyser med udgangspunkt i de konkrete sproglige og tekstlige retningslinjer (se niveau 3 i tabel 2) fra Sprogpolitik for Danmarks Domstole). Den eksplorative analyse giver således mulighed for at komme med en kvalificeret vurdering af om gennemførelsen af flere top down-analyser ville have nuanceret resultaterne. Viser der sig fx mange mulige tegn på forandringer som det kunne være værd at underkaste nærmere analyser, kunne det tyde på at der på andre områder end de undersøgte er sket forandringer med teksterne.

\section{Resultater af de eksplorative analyser}

Da der var tale om betydelige tekstmængder, var det praktisk umuligt at gennemlæse alle 48 domme. Jeg nøjedes derfor med at gennemlæse 3 gamle og 3 nye tilfældigt udvalgte domme fra hver af de to dommere (dvs. i alt 12 domme) og læste også de interviews jeg havde lavet med de to dommere.

Hverken gennemlæsningen af domme eller interviews gav mig nogen særlig anledning til at opstille hypoteser om forskelle mellem gamle og nye domme, jf. fx følgende uddrag fra interviewet med D1:

\section{Er der forskel på dine domme før og efter sprogpolitikken blev lanceret?}

Nej, det tror jeg ikke. Ikke noget der har tilknytning til sprogpolitikken, for jeg tror jeg skrev på den måde allerede før.
A. Kjærgaard
$13 / 28$
www.journals.uio.no 
Den eksplorative domsanalyse viste således ikke nogen oplagte tegn på forandringer i dommene. I parentes bemærket kunne det være interessant hvis man kunne kvalificere D1's påstand om at han skrev i overensstemmelse med det sprogpolitiske projekts anbefalinger allerede før det blev sat i værk. Hvis jeg skulle kvalificere udsagnet, ville det være mest oplagt at tage udgangspunkt i de konkrete sproglige og tekstlige anvisninger der danner udgangspunkt for mine analyser. I det perspektiv kan man ikke hævde at D1 skriver i fuldstændig overensstemmelse med projektets anbefalinger. Fx undgår D1 hverken i nye eller gamle domme konsekvent de "minusord" der blev udpeget som problematiske, og han anvender heller ikke konsekvent de anbefalede overskrifter. Men det udelukker ikke at sammenligninger mellem forskellige dommeres domme kunne vise at D1 i højere grad end så mange andre efterlever projektets anbefalinger.

\section{Det sprogpolitiske projekts (manglende) gennemslagskraft i Danmarks Domstole}

Spørgsmålet er så hvorfor det sprogpolitiske projekt ikke fik større gennemslagskraft i de analyserede tekster. I det følgende vil jeg præsentere en analysestrategi der kan bruges til at redegøre for hvordan man anskuede projektet fra forskellige positioner i Danmarks Domstole, og til at forklare hvorfor man anskuede projektet på forskellige måder.

\section{Udgangspunkt i den organisatoriske kontekst}

Med udgangspunkt i observationer i Danmarks Domstole fandt jeg at den organisatoriske kontekst spillede en helt central rolle for sprogpolitiske projekters gennemslagskraft. Jeg mente derfor at jeg havde brug for en bedre forståelse af den organisatoriske kontekst som det sprogpolitiske projekt udspillede sig i. Kjøller (1997) viste sig særligt interessant fordi han udpeger organisationskulturen som relevant, dvs. han inddrager begreber fra organisationsteorien i forsøget på at forklare hvorfor offentligt ansatte skriver som de gør. Det var en nærliggende tanke at organisationsteorier og -studier måtte kunne levere et begrebssæt jeg kunne systematisere, analysere og forstå mine data i forhold til.

\section{Individuelle fortolkninger}

Udgangspunktet for den følgende analyse er individuelle aktørers fortolkninger af det sprogpolitiske projekt. Således tager jeg udgangspunkt i en tilgang til organisationsanalysen - og til organisationer - der af Alvesson benævnes “aktörs- eller aktionssynssättet” (1990: 26). I denne tilgang fokuserer man på individer "vars innebörder och definitioner av situationer samt mål och avsikter utgör kärnan i verksamhet i organisationer” (ibid. 25).

At fokusere på fortolkninger er ifølge Alvesson \& Svenningson et spørgsmål om at undersøge "how people ascribe meaning to a particular phenomenon and find ways of defining and aligning their interests and themselves (identities) with others" (2008: 28, mine fremhævelser). Alvesson \& Svenningson giver konkrete eksempler på betydningstilskrivning af et organisatorisk kulturforandringsprojekt de analyserer, fx "managerial hypocrisy, paper product, ideal quite far away” (2008: 91-92, mine fremhævelser).
A. Kjærgaard
$14 / 28$
www.journals.uio.no 
Fordelen ved dette udgangspunkt var for det første at det gav mig mulighed for at forfølge min grundlæggende interesse for hvordan individuelle medarbejdere håndterer sprogpolitiske projekter. For det andet var mine data præget af en masse modstridende udsagn. Nogle medarbejdere gav fx udtryk for at der var tale om et vellykket projekt, mens andre tilskrev det sprogpolitiske projekt ringe betydning. Ved at bruge individuelle fortolkninger som udgangspunkt kunne jeg tage afsæt i disse mere eller mindre modstridende holdninger til projektet - og prøve at forstå hvordan de kunne eksistere side om side i den samme organisation.

\section{Hvad er aktørers individuelle fortolkninger baseret på?}

Fokusset på individuelle fortolkninger leder til spørgsmålet om hvad der motiverer disse fortolkninger. Hvorfor mener nogle medarbejdere $\mathrm{fx}$ at det er tale om et vellykket projekt, mens andre mener at der er tale om et temmelig ligegyldigt projekt? Jeg betragter individuelle fortolkninger som motiveret af kulturelle, strukturelle og individuelle faktorer.

Ved kultur forstår jeg antagelser og overbevisninger om hvordan tingene er eller bør være der deles af grupper af medarbejdere. Sådanne antagelser behøver ikke at være delt af alle i organisationen, de kan også være delt af bestemte grupper af medarbejdere, fx af gruppen af dommere i Danmarks Domstole (der i så fald udgør en subkultur i organisationen, se Schein (1994: kapitel 13 og 14)). Alvesson \& Svenningson (2008) er forankret i organisationskulturanalysen, dvs. hos dem er individuelle fortolkninger primært kulturelt motiveret, og det samme gælder Svenningsson \& Sörgärde (2007).

Ved struktur forstår jeg “den totale sum af dels de måder, hvorpå arbejdskraften opdeles i bestemte aktiviteter og dels de måder hvorpå disse aktiviteter kombineres”. Definitionen, der her er gengivet efter Sørensen (2000: 13, forfatterens fremhævelser), stammer fra organisationsteoretikeren Mintzberg (se fx Mintzberg 1993). Mintzberg arbejder ikke med individuelle fortolkninger, men hans fokus på hvordan arbejdskraften fordeles på forskellige opgaver, udgør et vigtigt bidrag til den følgende analyse.

Individuelle faktorer omfatter den enkelte aktørs personlige interesser, overbevisninger, oplevelser og uddannelse. Individuelle faktorer inddrages som et element der har betydning for individuelle fortolkninger hos Svenningsson \& Sörgärde (2007) - der, som påpeget ovenfor, også tilskriver organisationskulturen betydning for individuelle fortolkningers udformning.

\section{Analyse af det sprogpolitiske projekt i Danmarks Domstole}

I de følgende afsnit vil jeg forklare det sprogpolitiske projekts (manglende) gennemslagskraft ved at redegøre for forskellige aktørers fortolkninger af projektet og vise hvordan fortolkningerne er motiveret af strukturelle, kulturelle og individuelle faktorer.
A. Kjærgaard
$15 / 28$
www.journals.uio.no 
Hvis fortolkninger? Centralt, semilokalt og lokalt niveau

Jeg fokuserer på tre grupper af aktører i analysen:

\begin{tabular}{|l|l|}
\hline Centralt niveau & $\begin{array}{l}\text { Den gruppe af personer der tog initiativ til, planlagde og/eller i vidt } \\
\text { omfang gennemførte det sprogpolitiske projekt. }\end{array}$ \\
\hline Semilokalt niveau & De lokale retsledelser. Fokus er på ledelsen for Sø- og Handelsretten. \\
\hline Lokalt niveau & $\begin{array}{l}\text { Skrivende dommere, altså en af de medarbejdergrupper hvis skrivestil } \\
\text { man ønskede at forandre i kraft af det sprogpolitiske projekt. }\end{array}$ \\
\hline
\end{tabular}

Disse grupper af personer er særligt interessante fordi de, fra centralt niveau, var tiltænkt rollen som forandringsagenter, dvs. personer der "ved et scrligt engagement støtter implementeringen af et forandringsprojekt” (Petersen 2005: 44). Det er en central pointe at denne 3-deling og udpegning af forandringsagenter ikke forekom alle de aktører der indgår i analysen, lige selvfølgelig. Fokus er på at belyse hvordan projektet fortolkes fra forskellige niveauer i organisationen ved at sammenholde fortolkningerne på centralt, semilokalt og lokalt niveau. På det lokale niveau inddrager jeg derfor kun en enkelt dommer, D1, i analysen.

\section{Centralt niveau}

På centralt niveau fortolkes projektet gennemgående som relevant, dvs. som et projekt der var "vœesentligt $i$ den givne sammenhœeng" (jf. definitionen af "relevant" i Den Danske Ordbog, 2005). Spørgsmålet er hvordan kulturelle, strukturelle og individuelle faktorer hver især bidrog til denne fortolkning af projektet. Fokus er især på initiativtageren til projektet, den daværende direktør i Danmarks Domstole der var initiativtager til projektet, og derfor spillede en central rolle.

\section{Strukturelle faktorer}

En altafgørende strukturel faktor er oprettelsen af Domstolsstyrelsen - den organisatoriske enhed der tog initiativ til det sprogpolitiske projekt. Domstolsstyrelsen blev oprettet som selvstændig institution i 1999. Driften af domstolene havde tidligere ligget under Justitsministeriet, men ved etableringen af Domstolsstyrelsen løsrev man driften af domstolene fra et ministerium for i stedet at placere det i organisationen Danmarks Domstole. Domstolsstyrelsen er budgetansvarlig i forhold til retterne og har altså beføjelser til at træffe beslutninger om Danmarks Domstoles økonomi. Men derudover kan Domstolsstyrelsen ikke diktere retterne eller de enkelte dommere noget, og Domstolsstyrelsen udgør således ikke en form for øverste instans i Danmarks Domstole.

Etableringen af Domstolsstyrelsen var en nødvendig og klar forudsætning for at styrelsen kunne tage initiativ til projektet. At styrelsen rent faktisk tog initiativ til netop et sprogpolitisk projekt, var imidlertid ikke givet på forhånd. For at forstå hvorfor man tog initiativ projektet, er det nødvendigt at inddrage kulturelle og individuelle faktorer i analysen. 


\section{Kulturelle faktorer}

Spørgsmålet er hvilke antagelser og overbevisninger der lå til grund for at man fra centralt niveau fortolkede det sprogpolitiske projekt som relevant. På basis af min undersøgelse vil jeg karakterisere Danmarks Domstole som en organisation hvor de skrivende medarbejdere grundlæggende kan tilslutte sig en af følgende to antagelser: Den første antagelse er at medarbejderne i Danmarks Domstole i det store og hele skriver hensigtsmæssigt, dvs. at teksterne generelt er udtryk for et fornuftigt kompromis mellem de forskellige behov man må tage når man skriver tekster. For en doms vedkommende kan det $\mathrm{fx}$ dreje sig om hensynet til den juridiske præcision (herunder brugen af juridiske fagudtryk) og hensynet til at sagens parter skal have mulighed for at forstå den afgørelse der er truffet. Det er værd at bemærke at der er en tendens til at disse behov opfattes som modstridende: Hvis man fx skal gøre dommen forståelig for personer uden særlig juridisk indsigt, vil det ofte ske på bekostning af den juridiske præcision.

Den anden antagelse er at der skrives masser af tekster i Danmarks Domstole der kunne være skrevet langt mere hensigtsmæssigt. Blandt medarbejdere der tilslutter sig denne antagelse, vil man fx ofte mene at tendensen til at opfatte den juridiske præcision og forstålighed for almindelige mennesker som modstridende er delvist forfejlet. Derimod mener man at hensynet til den juridiske præcision og forståelighed for personer uden særlig juridisk indsigt godt kan tilgodeses på samme tid.

På centralt niveau var man af den opfattelse at teksterne fra Danmarks Domstole godt kunne skrives mere hensigtsmæssigt. På spørgsmålet i min interviewundersøgelse om hvorfor man i Domstolsstyrelsen gav sig til at arbejde med sproget, svarer direktøren:

Fordi sproget er fuldstcendigt afgørende på en eller anden vis for hvordan man opfatter domstolene, både det talte og det skrevne sprog. Hvis du skal fremstå som en moderne offentlig myndighed, så kan du ikke henvende dig i et gammeldags, bureaukratisk sprog til borgerne. Og det gcelder både i retten og i dommene. Det har i den grad vcret et ønske om at markere et stilskifte og en bevidstgørelse også fra dommerside, fordi det er jo også meget proces det her, at man kan tage fat på at udvikle en ydelse, se det fra en borgers synsvinkel. Og så er sproget altså helt elementcert, det er vores redskab til at udtrykke os med.

Direktøren mente altså at der var masser at tage fat på hvis man ville forbedre sprog og tekster fra Danmarks Domstole. Her i citatet knytter direktøren ønsket om at ændre sproget til et ønske om at ændre organisationens image. Han taler således om at "markere et stilskifte" og understreger at hvis man vil fremstå "moderne" så hjælper det ikke at bruge et "gammeldags, bureaukratisk sprog til borgerne". Hensynet til almindelige borgeres forståelse af tekster spillede dog også en rolle for direktøren og antydes også i citatet hvor han taler om at "udvikle en ydelse" ved at se på sprog og tekster "fra en borgers synsvinkel". 


\section{Individuelle faktorer}

Oprettelsen Domstolsstyrelsen skabte altså en potentiel platform for det sprogpolitiske projekt (strukturel faktor), og antagelsen om at teksterne i Danmarks Domstole var karakteriseret af nogle generelle uhensigtsmæssigheder der burde rettes op på (kulturel faktor), var hver især med til at skabe mulighed for at det sprogpolitiske projekt kunne fortolkes som relevant, og dermed værd at sætte i værk.

Det er imidlertid ikke nok til at forklare at projektet rent faktisk blev sat i værk. Her var det ikke alene vigtigt at den daværende direktør mente at teksterne fra Danmarks Domstole i mange tilfælde ikke var særligt hensigtsmæssige. Det var også af afgørende betydning at spørgsmålet om sprog og tekster faktisk forekom ham så relevant at han valgte at iværksætte projektet.

På spørgsmålet om hvorvidt behovet for en sprogpolitik var "påtrcengende” da man iværksatte projektet, svarede direktøren:

Jeg synes helt klart at der var behov for løft i sproget. Man kan sige at sigtet var dobbelt. Det var både at få et bedre produkt ud, men det var i høj grad også at få en organisation $i$ tale og få til at tale om ømfindtlige kerneområder som det at skrive en dom det vitterligt er. Og vise at der er altså plads til en diskussion af det her, og man kan drøfte sådan noget uden at give afkald på noget som helst. (...) Så det var både et ønske om at drive en udvikling i retning af at gøre en organisation mere diskussionslysten og åben over for de centrale diskussioner og så selvsagt at få et bedre produkt ud af det, altså mere velskrevne og lettere forståelige breve og domme.

Citatet er illustrativt fordi direktøren starter med at understrege sit eget personlige engagement ved at sige at det var ham ("jeg") der synes der var behov for et løft i sproget. Umiddelbart vurderer direktøren altså, at han som enkeltperson spillede en afgørende rolle for at det sprogpolitiske projekt blev fortolket som relevant - og iværksat.

Direktøren udpeger derudover to formål med projektet: for det første et sprogligt mål, nemlig at bidrage til et "løft i sproget", for det andet et organisatorisk mål, nemlig at "få en organisation $i$ tale" og "drive en udvikling i retning af at gøre en organisation mere diskussionslysten og åben over for de centrale diskussioner". Direktøren antyder at disse mål kan være forbundne med bestemte vanskeligheder: Det at skrive en dom omtales som et "ømfindtligt kerneområde", og direktøren siger også at han med det sprogpolitiske projekt ville vise at "man kan drøfte sådan noget [altså sprog og tekster] uden at give afkald på noget som helst". Dette sidste udsagn kan forekomme noget gådefuldt, men svaret på hvem der er bange for at miste hvad, er nøglen til at forstå vigtige elementer af det sprogpolitiske projekts organisatoriske kontekst. Kort sagt handler det om dommerstandens uafhængighed - en faktor direktøren for Domstolsstyrelsen altså var fuldt ud bevidst om, og som vil spille en vigtig rolle $\mathrm{i}$ analysen af det semilokale og lokale niveau. 
En anden vigtig individuel faktor hos direktøren var at han var villig til at stille sig i spidsen for et projekt der nærmede sig dommernes skrivning som et kollektivt anliggende. Formålet var ikke at diktere dommerne at de skulle skrive på en bestemt måde, det ville være et brud med dommernes grundlovssikrede uafhængighed. Formålet var derimod at få sat gang i en fælles diskussion af hvad der kendetegner godt sprog i domme, og få nedfældet nogle fælles anbefalinger for organisationens tekster ${ }^{11}$.

Som det vil fremgå af det følgende, blev initiativet ikke anset for at være helt uproblematisk på semilokalt og lokalt niveau.

\section{Semilokalt niveau}

Det semilokale niveau hos Sø- og Handelsretten repræsenteres af de to personer der på daværende tidspunkt udgjorde ledelsen: retspræsidenten og justitssekretæren. Retspræsidenten havde ansvaret for administration, fordeling af sager, personale og budget og fungerede i øvrigt som dommer. Justitssekretæren fungerede som administrationschef, dvs. assisterede retspræsidenten med det administrative arbejde. To gennemgående fortolkningsaspekter på semilokalt niveau var at det sprogpolitiske projekt var problematisk og mindre relevant. Som jeg allerede har været inde på, opfattede man på centralt niveau projektet som relevant, dvs. som "vœsentligt i den givne sammenhæeng". Med mindre relevant vil jeg indfange den pointe at man på semilokalt niveau tilskrev diskussionen af sprog og tekster generel relevans. Det kommer fx til udtryk i et udsagn fra retspræsidenten om at "der er altid behov for en sprogpolitik (...) overvejelser om om det man gør, er det rigtige”. Imidlertid mente man ikke at det sprogpolitiske projekt i dets konkrete udformning passede ind i den organisatoriske kontekst.

\section{Strukturelle faktorer}

Den strukturelle faktor der spillede den største rolle for fortolkningen af det sprogpolitiske projekt på semilokalt niveau, var domstolenes og den enkelte dommers uafhængighed. Hvad angår skrivning af domme, betyder det at dommerne alene er forpligtet til at følge lov om dansk retskrivning, dvs. følge dansk retskrivning som den er fastlagt af Dansk Sprognævn. Alt hvad der i øvrigt vedrører dommes udformning (fx formulering og disponering af stoffet), er op til den enkelte dommer. Danske dommere er således heller ikke omfattet af den danske forvaltningslov, herunder formuleringen om at

\footnotetext{
${ }^{11}$ Den endelige udgave af Sprogpolitik for Danmarks Domstole har karakter af en række færdige anbefalinger, og ønsket om at sætte gang i en diskussion fremstår ikke særligt tydeligt. For de fleste ansatte i Danmarks Domstole vil det dog være klart at der ikke kan være tale om et påbud: Domstolsstyrelsen er budgetansvarlig i forhold til retterne, men det ligger uden for styrelsens beføjelser at udstede sproglige påbud. Desuden var processen med at udarbejde Sprogpolitik for Danmarks Domstole tilrettelagt sådan at sprogudvalget sendte et udkast af skriveguiden ud til kommentering hos de enkelte retter (denne arbejdsgang med nedsættelse af udvalg og høring hos retterne er typisk for Domstolsstyrelsens arbejde i forhold til retterne, dvs. der blev ikke tilrettelagt en særlig diskussionsfremmende arbejdsgang i forbindelse med det sprogpolitiske projekt).
} 
[v]ed den sproglige udformning af forvaltningsafgørelser bør myndigheden have for øje, at enhver, som teksten henvender sig til, let skal kunne læese og forstå den. Herudover bør den vcere formuleret venligt og hensynsfuldt (Vejledning om forvaltningsloven, 1986).

Ingen, heller ikke Domstolsstyrelsen, har altså beføjelser til at beslutte at dommerne fx skal forsøge at anslå en bestemt tone over for modtageren eller skal foretrække bestemte ord og vendinger frem for andre.

Disse forhold var man naturligvis udmærket klar over i Domstolsstyrelsen, og Sprogpolitik for Danmarks Domstole indeholder da også en række anbefalinger, ikke påbud. Det er på den anden side vigtigt at understrege at en diskussion af hvordan man skriver domme og udarbejdelsen af et sæt ikke-forpligtende anbefalinger, ikke i sig selv er i modstrid med dommeruafhængigheden. At det sprogpolitiske projekt blev mødt med modstand, og at denne modstand i vidt omfang blev begrundet med henvisning til dommeruafhængigheden, må også forstås under inddragelse af kulturelle faktorer.

\section{Kulturelle faktorer}

En af de vigtige kulturelle antagelser er antagelsen om at det er op til den enkelte dommer hvordan vedkommende skriver sine domme - det skal hverken Domstolsstyrelsen, dommerkolleger eller ledelsen for Sø- og Handelsretten afgøre.

Retspræsidentens og justitssekretærens holdning til det sprogpolitiske projekt må ikke forveksles med deres holdning til sprog ved domstolene. Sproget i domme og i domstolenes virke i det hele taget tilskrives stor vigtighed. Derimod opfattede ingen af de to informanter det sprogpolitiske projekt som et særligt relevant bidrag til skrivearbejdet, jf. fx interviewet med retspræsidenten:

\section{Har du lcest den [dvs. publikationen Sprogpolitik for Danmarks Domstole]?}

Noget af den. Jeg har ikke studeret den scerligt grundigt, og det jeg har leest, forekom mig ikke scerligt interessant. Det var noget man vidste i forvejen. Nogle af tingene er interessante men måske problematiske fordi der forsøger man at indføre nogle andre ord $i$ stedet for nogle hæevdvundne ord hvor de hcevdvundne ord i hvert fald har den fordel at de er meget prcecise og rammer det. Og der er det jo der hvor jurister i hvert fald vil sige det her ord det er lige prcecis det vi bruger. Så ved alle hvad det er, og det rammer helt prcecist. En modernisering eller en fornyelse af sproget på sådan nogle områder der, det kan føre til at man skriver noget som ikke er helt så prcecist. Så der er dele af sprogpolitikken, en mindre del, som ikke er noget fremskridt. Men det ville vcere løgn at sige at den har gjort noget scrligt indtryk på mig i det hele taget.

Tilsvarende siger justitssekretæren:

(...) mange af rådene vil jeg sige, enten er de rimeligt selvfølgelige, eller også er det sådan noget der ncermest udarter til religionskrig, og som derfor er svcert at lave fcelles retningslinjer for.
A. Kjærgaard
$20 / 28$
www.journals.uio.no 
Problemet ved det sprogpolitiske projekt er altså på den ene side at rådene var "noget man vidste $i$ forvejen" eller "rimeligt selvfølgelige". På den anden side var dele af indholdet mere problematisk, nemlig forsøget på at indføre andre ord end de "hœvdvundne” eller temaer der "udarter til religionskrig”, og som man derfor næppe kan nå til enighed om.

Det kunne lede en til at mene at det sprogpolitiske projekt har satset på det forkerte indhold, altså fx givet anbefalinger af en karakter der ikke passede til en ret som Sø- og Handelsretten. Hvis man fokuserer entydigt på indholdsniveauet, mener jeg imidlertid at man overser at der er noget mere grundlæggende på spil der vedrører forholdet mellem Domstolsstyrelsen og retterne herunder spørgsmålet om hvem der udstikker retningslinjerne for hvordan domme skal skrives. Denne problemstilling berøres i følgende uddrag fra interviewene med hhv. justitssekretæren og retspræsidenten:

Er det [altså forholdet mellem retterne og Domstolsstyrelsen] sådan lidt ambivalent? Skal Domstolsstyrelsen lade vare med at stikke piben alt for langt frem (...)?

Altså, det tror jeg nok at de skal lade vcre med. Og det mener jeg da også at de skal lade være med. Og det kan der vare flere grunde til at de skal lade vcere med. For det første, altså på sådan et punkt her der kommer de nemt i karambolage med det som er den enkelte dommers grundlovssikrede ret - jeg skriver mine domme som jeg vil. Så det er virkeligt noget man skal tænke over hvis man vil ind og påvirke noget, hvordan kan man gøre det. Og man kan ikke gøre det ved at sende retningslinjer ud eller prøve ligesom at presse noget ned. Man er nødt til at få folk til at arbejde med selv eller vakke interessen på en eller anden måde, og så lade det gro nedefra. Og det er, det synes jeg nok ikke Domstolsstyrelsen er så gode til at få sat noget i gang der gør at ting vokser op nedefra. De er klart bedre til at forsøge at styre oppefra.

Du har ikke som prcesident haft nogen scerlig... følt dig forpligtet til at sprede det glade budskab eller sådan et eller andet?

Nce, altså når vi begynder at tale om pligt, så vil jeg bare sige jeg har ikke nogen som helst pligt til at følge sprogpolitikken, det er et helt uforpligtende udkast, og Domstolsstyrelsen har jo, det er dem der er forfattere, ikke?

Jo.

Domstolsstyrelsen har jo slet ikke nogen kompetence til at blande sig, så det anser jeg bare for sådan en eller anden sjov lille pjece de har lavet.

Både justitssekretæren og retspræsidenten henviser til de strukturelle forhold, nemlig at det er op til dommerne selv at afgøre hvordan de vil skrive deres domme (og i det omfang Domstolsstyrelsen overhovedet skal blande sig i det, så skal de, efter justitssekretærens opfattelse, gøre det med større varsomhed).

Modstanden mod det sprogpolitiske projekt funderes altså strukturelt, men de strukturelle forhold er ikke tilstrækkelige til at forklare den. Dommeruafhængigheden forbyder ikke dommerne at
A. Kjærgaard
$21 / 28$
www.journals.uio.no 
udarbejde nogle fælles anbefalinger for fx domsskrivning som det så stod den enkelte fuldstændigt frit at afvige hvis der var gode grunde til det. Men et sådan forsøg opfattes som irrelevant og problematisk på semilokalt niveau fordi det går imod en meget stærk antagelse om at skrivning af domme er et område hvor den enkelte dommer bør råde suverænt - ikke bare fordi dommerne har ret til at hævde deres uafhængighed, men også fordi de som dommere er forpligtede at hævde den. Analysen af det centrale niveau viste at direktøren bl.a. så projektet som en mulighed for at få Danmarks Domstole "i tale og få til at tale om ømfindtlige kerneområder”. Sø- og Handelsretten var imidlertid ikke voldsomt interesseret i at indgå i en sådan dialog - i hvert fald ikke når talen faldt på skrivning af domme.

Individuelle faktorer

Jeg har ikke kunnet finde tegn på at individuelle faktorer spillede nogen særlig rolle på semilokalt niveau, dvs. at der var elementer i fortolkningen af projektet der hverken kunne tilskrives kulturelle eller strukturelle faktorer.

\section{Lokalt niveau}

Fokus for analysen er vertikalt snarere end horisontalt: Det primære formål er at sammenholde fortolkningerne på centralt, semilokalt og lokalt niveau. Jeg fokuserer således kun på den ene af de to dommere hvis domme jeg analyserede i første del af artiklen, nemlig D1. En af de helt centrale fortolkningskomponenter hos D1 er at der er tale om et mindre relevant men dog ganske sympatisk projekt.

\section{Strukturelle faktorer}

Det er de samme strukturelle faktorer der gør sig gældende på lokalt som på semilokalt niveau. Den strukturelle faktor der er mest relevant for D1, er dommeruafhængigheden, herunder retten til selv at afgøre hvordan domme skal udformes.

\section{Kulturelle faktorer}

D1 tilslutter sig antagelsen om at skrivning af domme er dommernes eget anliggende, og at andre derfor skal være meget varsomme med at blande sig:

Men er det ok at der er sådan en grundlaggende konsensus som den der er i sprogpolitikken, (...) om hvordan man ligesom helt grundlaggende skal gøre?

Jo, det kan man godt, men panser og plade hvor man bliver bundet til at skrive noget på en bestemt måde det tror jeg ikke dur. Det vil dommerne, altså dommere er jo uafhcengige, og det er de også som personer. Det prceger altså også deres personlighed at de vil ikke vcere bundet af noget. Så jo mere man prøver at presse ned over dem jo større vanskeligheder vil man skabe for projektet.

Der er ikke noget galt med konsensus, men det vigtigste er at man ikke antaster dommernes uafhængighed. Frem for at have som mål at få ensartet sprog og formidlingsform, så er det vigtigste at der er plads til "dommerindividualitet”:
A. Kjærgaard
$22 / 28$
www.journals.uio.no 
Synes du at det er et mål for Danmarks Domstole at sproget og formidlingsformen $i$ domme og retsbøger er relativt ensartet? Eller er det vigtigere at den enkelte dommer ligesom finder sin egen stil?

Jeg mener ikke det skal være ensartet, jeg mener der skal være plads til dommerindividualitet, det tror jeg er meget nødvendigt.

Domsskrivning er et område hvor den enkelte dommer råder suverænt, og Domstolsstyrelsens ønske om at identificere, nedskrive og promovere et fælles udgangspunkt for domsskrivning opfattes som mindre relevant. Ved analysen af det centrale niveau pegede jeg på at medarbejderne i Danmarks Domstole kunne tilslutte sig en af følgende to antagelser: Enten at medarbejderne i det store og hele skriver hensigtsmæssige tekster, eller at der skrives masser af tekster der på mange måder ikke er særligt hensigtsmæssige. D1 placerer sig, sammen med direktøren for Danmarks Domstole, meget entydigt i den lejr som mener der skrives masser af uhensigtsmæssige tekster. På spørgsmålet om om Danmarks Domstole havde behov for en sprogpolitik på lanceringstidspunktet, svarer han:

I høj grad. Og det har vi sådan set stadig. Hvis du læeser vores domme, så starter man stadigvæk år 2008 den sådan og sådan blev af Sø- og Handelsretten afsagt sålydende dom. Sådan skriver man stadigvcek nogle steder.

D1 og direktøren for Domstolsstyrelsen er altså enige om at teksterne fra Danmarks Domstole kunne forbedres. Således er det karakteristisk for D1's fortolkning af projektet at han også betragter det med en vis sympati. D1 er imidlertid ikke stemt for en løsning der kommer udefra, altså fx fra Domstolsstyrelsen. I det omfang skrivning af domme skal diskuteres, skal diskussionen snarere tages op internt i dommergruppen.

\section{Individuelle faktorer}

Ud over de strukturelle og kulturelle faktorer var der også en individuel faktor der føjede en ekstra dimension til D1’s fortolkning af projektet som sympatisk. Således var D1 en blandt de få jeg mødte i Danmarks Domstole, der mente at hans tekster allerede var i overensstemmelse med anbefalingerne fra det sprogpolitiske projekt, jf. citatet fra D1 tidligere i artiklen hvor han siger at han "skrev på den måde allerede før [sprogprojektet]". D1's personlige overbevisning om at hans egne tekster allerede var i overensstemmelse med det sprogpolitiske projekt, understøtter hans fortolkning af projektet som mindre relevant for ham personligt, men dog ganske sympatisk.

\section{Opsummering}

Formålet med denne artikel var at redegøre for hvordan og hvorfor et konkret eksempel på et sprogpolitisk projekt fik en bestemt gennemslagskraft. Tekstanalysen af D1's og D2's domme viste ikke nogen overbevisende tegn på at det sprogpolitiske projekt havde haft nogen særlige effekter i forhold til de analyserede tekster. Som udgangspunkt for organisationsanalysen
A. Kjærgaard
$23 / 28$
www.journals.uio.no 
fokuserede jeg på fortolkninger af projektet på tre forskellige niveauer i Danmarks Domstole: det centrale niveau (dvs. Domstolsstyrelsen der tog initiativ til projektet), det semilokale niveau (dvs. ledelsen i Sø- og Handelsretten) og det lokale niveau (repræsenteret ved D1, en af de to dommere hvis tekster blev analyseret i tekstanalysen). I skemaet nedenfor har jeg opsummeret resultaterne af analysen ved at anføre de udvalgte, vigtige fortolkningsaspekter samt de kulturelle, strukturelle og individuelle faktorer der motiverer disse fortolkningsaspekter.

\begin{tabular}{|c|c|c|c|c|}
\hline $\begin{array}{l}\text { Fortolknings- } \\
\text { niveau }\end{array}$ & $\begin{array}{l}\text { Fortolknings- } \\
\text { aspekter - } \\
\text { ”det sprog- } \\
\text { politiske } \\
\text { projekt er..." }\end{array}$ & $\begin{array}{l}\text { Strukturelle } \\
\text { faktorer }\end{array}$ & $\begin{array}{l}\text { Kulturelle } \\
\text { faktorer }\end{array}$ & $\begin{array}{l}\text { Individuelle } \\
\text { faktorer }\end{array}$ \\
\hline $\begin{array}{l}\text { Centralt } \\
\text { niveau }\end{array}$ & relevant. & $\begin{array}{l}\text { Oprettelsen af } \\
\text { Domstolsstyrelsen }\end{array}$ & $\begin{array}{l}\text { Masser af tekster } \\
\text { kunne være } \\
\text { skrevet langt mere } \\
\text { hensigtsmæssigt }\end{array}$ & $\begin{array}{l}\text { Direktørens stærke } \\
\text { personlige } \\
\text { engagement }\end{array}$ \\
\hline $\begin{array}{l}\text { Semilokalt } \\
\text { niveau }\end{array}$ & $\begin{array}{l}\text { problematisk og } \\
\text { mindre } \\
\text { relevant. }\end{array}$ & $\begin{array}{l}\text { Dommer- } \\
\text { uafhængigheden }\end{array}$ & $\begin{array}{l}\text { Skrivning er } \\
\text { dommeres egen } \\
\text { sag }\end{array}$ & \\
\hline Lokalt niveau & $\begin{array}{l}\text { et mindre } \\
\text { relevant men } \\
\text { dog ganske } \\
\text { sympatisk } \\
\text { projekt. }\end{array}$ & $\begin{array}{l}\text { Dommer- } \\
\text { uafhængigheden }\end{array}$ & $\begin{array}{l}\text { Skrivning er } \\
\text { dommeres egen } \\
\text { sag }\end{array}$ & $\begin{array}{l}\text { Skriver allerede i } \\
\text { overensstemmelse } \\
\text { med projektets } \\
\text { anbefalinger }\end{array}$ \\
\hline
\end{tabular}

Forklaringerne er opstillet med udgangspunkt i interviews og observationer i organisationen, men er ikke at forstå som parafraser af de holdninger til og refleksioner over det sprogpolitiske projekt som jeg blev præsenteret for hos forskellige medarbejdere og i dokumenter om projektet. Tværtimod er skemaet ovenfor resultatet af en grundig analyse af interviews, observationer og dokumenter om det sprogpolitiske projekt for at kunne indkredse de grundlæggende strukturelle, kulturelle og individuelle faktorer der spillede en afgørende rolle for det sprogpolitiske projekts gennemslagskraft.

Formålet med min undersøgelse var kvalitativt, dvs. målet var ikke at undersøge hvordan det sprogpolitiske projekt slog igennem i Danmarks Domstole generelt. Afsluttende er det dog værd at overveje i hvilket omfang resultaterne kan generaliseres til resten af Danmarks Domstole. Hvad angår tekstanalysen, mener jeg at man skal være varsom med at generalisere. Man kan konstatere at der er eksempler på at det sprogpolitiske projekt ikke har haft nogen særlig tekstlig gennemslagskraft, men der kan sagtens være andre dommere i Sø- og Handelsretten eller i andre retter der i langt højere grad har indarbejdet anbefalingerne fra Sprogpolitik for Danmarks
A. Kjærgaard 
Domstole i deres domme. Hvad angår organisationsanalysen, er grundlaget for generaliseringer bedre. I denne analyse identificerede jeg nemlig en række kulturelle og strukturelle faktorer der efter al sandsynlighed gør sig gældende i andre retter i Danmarks Domstole, og kan have haft en tilsvarende betydning for hvordan andre medarbejdere har fortolket projektet. Faktorer som dommeruafhængigheden og den stærke antagelse om at skrivning er dommeres egen sag, er således ikke særlige træk ved Sø- og Handelsretten, men faktorer der spiller en rolle i hele Danmarks Domstole.

Diskussioner om hvad man kunne have gjort i stedet for, hvordan man alternativt kunne have grebet det sprogpolitiske projekt i Danmarks Domstole an, kan forekomme en anelse letkøbte når man sidder som udenforstående forsker på sikker tidslig, fysisk og mental afstand af den organisatoriske kontekst som projekterne er blevet til i. På den anden side kan man mene at forskning i et så praksisnært felt forpligter - ikke bare til at udpege problemerne, men også til at reflektere over hvad man kunne have gjort anderledes.

I løbet af mit arbejde med Danmarks Domstole slog det mig først og fremmest at man i højere grad kunne have arbejdet med udgangspunkt i de muligheder der faktisk var for at ændre de skrivende medarbejderes tekster og holdninger til hvad der udgør hensigtsmæssige tekster. Dommerne gav fx udtryk for et meget højt niveau af sproglig bevidsthed, og det undrede mig længe at mange af disse så sprogligt bevidste dommere virkede temmelig uinteresserede i Sprogpolitik for Danmarks Domstole. Måske kunne man i langt højere grad have inddraget dommerne, og for den sags skyld andre skrivende medarbejdere i organisationen, hvis man havde introduceret det sprogpolitiske projekt som en slags vidensdelingsprojekt, dvs. have skabt et forum hvor fx dommere kunne diskutere sproglige og tekstlige aspekter af andres og egne domme. På den måde kunne man have gjort brede grupper af dommere og andre skrivende medarbejderne til mere aktive deltagere i diskussionen om hvad der udgør den gode dom, det gode brev eller den gode retsbog. Man kan indvende at sådanne kursus- eller seminarrækker næppe ville appellere til alle dommere eller andre grupper af skrivende medarbejdere. På den anden side kunne man forestille sig at dem der deltog, ville få langt større udbytte fordi de blev gjort til aktive deltagere i diskussionen snarere end passive modtagere af en pjece med en række anbefalinger som det var alt for let at ignorere.

Som analysen også har vist, er Danmarks Domstole imidlertid ikke nogen helt almindelig organisation i den forstand at dommernes uafhængighed giver nogle helt særlige rammer for hvilket råderum den initiativtagende institution, altså Domstolsstyrelsen, havde. Og netop her gemmer en af undersøgelsens centrale pointer sig: Selvom formålet med sprogpolitiske projekter måske for en overfladisk betragtning kan se ganske ens ud, det handler fx ofte om at få medarbejderne til at skrive tekster der er lettere og forstå og mere imødekommende, så udspiller projekterne sig i helt forskellige organisatoriske kontekster der på forskellig vis påvirker deres gennemslagskraft. Her i undersøgelsen har jeg løftet en lille flig af det tæppe der dækker over den mængde af mangeartede organisationer sprogpolitiske projekter udspiller sig i - og tilsvarende studier i andre organisationer vil kunne kaste lys over flere dimensioner af denne diversitet. 


\section{Litteratur}

Alvesson, M. (1990). Kommunikation Makt och Organisation. Kritiska tolkningar av ett informationsmöte i ett företag. Stockholm: Nordstedts Ekonomi.

Alvesson, M., \& Sveningsson, S. (2008). Changing Organizational Culture. Cultural change work in progress. London: Routledge.

Becker Jensen, L. (1998). Kancellistil eller Anders And-sprog? - en undersøgelse af forvaltningssproget og dets institutionelle betingelser (2. udgave). Frederiksberg: Roskilde Universitetsforlag.

Carlsen, K. (2008). Er det stadig sort snak? - Forpligtelsen og effekten af Danmarks Domstoles sprogpolitik. Upubliceret speciale afleveret ved Institut for Nordiske Studier og Sprogvidenskab, Københavns Universitet.

Cheek, A. (2010). Defining plain language. Clarity 64, 5-15.

Danmarks Domstole, nr. 17 (2003). Temanummer om Sprogpolitik for Danmarks Domstole. Domstolsstyrelsen. Hentet d. 1.11. 2011 fra http://www.domstol.dk/om/publikationer/HtmlPublikationer/Danmarks\%20Domstole/D anmarks\%20Domstole\%20nr.\%2017/index.htm.

Den Danske Ordbog, bd. 1-6. (2003-2005). København: Det Danske Sprog- og Litteraturselskab, Gyldendal. Hentet 1.112011 fra http://ordnet.dk/ddo/.

Domstolsstyrelsen. (2003). Sprogpolitik for Danmarks Domstole. København:

Domstolsstyrelsen. Hentet 6.10. 2011 fra

http://www.domstol.dk/om/publikationer/HtmlPublikationer/Politikker/Sprogpolitik/97 8-87-92357-17-4.pdf.

Eyben, W.E. von (1962): Juridisk grundbog. Affattelse af love domme, forvaltningsakter og kontrakter. København: Juristforbundets Forlag.

Gunnarsson, B. L. (1997). The Writing Process from a Sociolingustic Viewpoint. Written Communication 14(2), 139-188.

Hansen, E. (1971). Ping- og pampersprog. København: Hans Reitzels Forlag.

Henriksen, L., Jongejan, B., \& Maegaard, B. (2004). Controlled Language promoting readability and Tone-of-Voice. I: J. O. Fretland \& M. Hovdenak (Red.), Forståeleg språk for alle. Rapport frå ein nordisk konferanse om klarspråk (s. 82-88). Oslo: Nordens Språkråd. Hentet 1.112011 fra http://www.nordisksprakrad.no/Komplett\%20Klarspr\%C3\%A5k.pdf.

Janssen, D. (2001). Improving the quality of public documents: Or: Why training public writers often doesn't work. I: D. Janssen \& R. Neutelings (Red.), Reading and Writing Public Documents (s. 105-124). Amsterdam: John Benjamins Publishing Company.

Jarvad, P. og J. Schack - i samarbejde med Sprog- og designgruppen hos Folketingets Ombudsmand (2008). Håndbog i klarsprog for ansatte hos Folketingets Ombudsmand. København: Folketingets Ombudsmand.

Karker, A. (1982). Ti år efter eller Lovsprogets forandring. Scrtryk af Festskrift til Professor, dr. jur. W.E. von Eyben. København: Juristforbundets Forlag.

Khan, E. J. J. (2010). Afkomplicering af juridisk sprog. Upubliceret speciale afleveret ved Institut for Internationale Sprogstudier og Vidensteknologi, CBS. Hentet 11.1.2011 fra 
http://studenttheses.cbs.dk/bitstream/handle/10417/1016/eiliyah_julie_jacobsen_khan.p df? sequence $=1$.

Kjærgaard, A. (2007). Skriv fagligt, sagligt, venligt, korrekt, entydigt og klart så det afspejler organisationens troværdighed, kvalitetsbevidsthed og effektivitet. Øh...Hvordan er det nu lige man skriver sådan?. I: M. Heidemann Andersen \& J. Nørby Jensen (Red.), Bag ordene. Festskrift til Ole Ravnholt i anledning af 60-års-dagen (s. 79-90). København: Dansk Sprognævn.

Kjærgaard, A. (2010). Sådan skriver vi - eller gør vi? - En undersøgelse af de tekstlige effekter af to sprogpolitiske projekter i Danmarks Domstole og Københavns Kommune og af årsagerne til projekternes gennemslagskraft. (Ph.d.-afhandling, Københavns Universitet). København: Københavns Universitet.

Kjærgaard, A. (2011). Nytter det? - Om de tekstlige effekter af sprogpolitiske projekter i offentlige institutioner. NyS 40, 90-116.

Kjærgaard, A. (indleveret til bedømmelse): Om hvorfor offentligt ansatte ikke bare ændrer skrivestil - fra problemmodel til fortolkningsmodel.

Kjøller, K. (2004). Tekst for viderekomne. Tekstproduktion og sproglig rådgivning. Frederiksberg: Samfundslitteratur.

Kjøller, K. (1997). Image - Effektive råd til virksomheden om sprog og kommunikation. København: Akademisk Forlag.

Mintzberg, H. (1993). Structure in Fives, Designing Effective Organizations. Englewood Cliffs, N.J.: Prentice-Hall.

Mortensen, F. (1971): Kommunikationskritisk analyse af 22-radioavisen. Århus: GMT Møller, B. \& Hansen, E. (1981) - og uden omsvøb, tak! Statens Informationstjeneste.

Nyström Höög, C. (2010). Kursändring i klarspråksarbetet? Om myndighetsspråkvård och språkforskning. I: L. Andersson, O. Josephson, I. Lindberg, M. Thelander (Red.), Språkvård och språkpolitik. Svenska språknämndens forskningskonferens i Saltsjöbaden 2008 (120-138). Språkrådet 2009. Stockholm: Norstedts.

Pedersen, K. (2006). Organistens spagat - offentlig kommunikation ved en skillevej. I: Karsten Pedersen, Birgitte Ravn Olesen og Roy Langer (red.): Offentlig kommunikation i spagat (s. 121-129). København: Handelshøjskolens Forlag.

Petersen, H. (2005). Forandringskommunikation. Frederiksberg: Samfundslitteratur.

Poulsen, I. (1976). Skriv bedre. Nogle bemcerkninger til arbejdet med skriftlig fremstilling. Tune: Landbrugets Informationskontor.

Rasmussen, G. (1974). Sportsjournalistik. En pragmatisk og ideologikritisk undersøgelse. Kongerslev/Grenå: GMT.

Ramskov, C. \& Nederveen, R. (2008). En effektmåling af Patent- og Varemæerkestyrelsens sprogpolitik. Upubliceret speciale afleveret ved Copenhagen Business School.

Schein, E. H. (1994). Organisationskultur og ledelse. Holte: Forlaget Valmuen.

Shriver, K. \& Gordon, F. (2010). Grounding plain language in research. Clarity 64, 33-39.

Solomon, N. (1996). Plain English: from a perspective of language in society. I: R. Hasan \& G. Williams (Red.), Literacy in Society (s. 279-307). London: Longman.

Sprogpolitik for Danmarks Domstole (2003). København: Domstolsstyrelsen, 2003. Hentet 11.1.2011 fra 
http://www.domstol.dk/om/publikationer/HtmlPublikationer/Politikker/Sprogpolitik/97 8-87-92357-17-4.pdf.

Sveningsson, S. \& N. Sörgärde (2007), Organisationsförändring - från ingenjörskonst till tolkning. I M. Alvesson \& S. Sveningsson (Red.), Organisationer, ledning och processer (s. 237-268). Lund: Studentlitteratur.

Sørensen, N. B. (2000). Organisationers form og funktion (4. udgave). Frederiksberg: Samfundslitteratur.

Søndergaard, Y. (2010). Sprogpolitik, passiver og kancellisløjfer. Nyt fra Sprogncevnet, 2, 6-8. Hentet $1.112011 \mathrm{fra} \mathrm{http://dsn.dk/nyt/nyt-fra-sprognaevnet/2010-2.pdf.}$

Vejledning om forvaltningsloven (nr. 11740 af 04/12/1986). Hentet 15.10. 2011 fra http://www.ladk.dk/jura/y-files/vejl_fvl.htm.

Vejledning om sproget i love og andre retsforskrifter. Justitsministeriets vejledning af 15. oktober 1969. Hentet 15.10. 2011 fra https://www.retsinformation.dk/Forms/R0710.aspx?id=60796.

Wille, N. E. (2001). Det gode sprog. Nogle tanker om det forskningsmæssige grundlag for rådgivning om sproget i faglig formidling”. I: Lars Heltoft og Carol Henriksen (Red.), Den analytiske gejst. Festskrift til Uwe Geist på 60-årsdagen 23. september 2001 (s. 259-271). Frederiksberg: Roskilde Universitetsforlag.

Wray, A. \& Perkins, M. R. (2000). The functions of formulaic language: an integrated model. Language \& Communication, 20(1), 1-28. 